\title{
Chapter 28 \\ Student Academic Misconduct Through \\ a Canadian Legal Lens
}

\author{
Melissa Morrison and Philip Zachariah
}

\begin{abstract}
The processes that post-secondary institutions use to detect, investigate, judge and discipline cases of academic misconduct are shaped by legislative and judicial requirements including procedural fairness. This chapter situates post-secondary institutions' options on addressing allegations of academic misconduct in the broader Canadian legal context. Reviewing leading Court cases, including those where students appealed findings of misconduct, this chapter analyses the key principals that post-secondary institutions should adhere to in order to provide sufficient procedural fairness. We conclude with practical considerations that post-secondary institutions can take to minimize decisions about academic misconduct being overturned by the Courts.
\end{abstract}

Keywords Academic integrity $\cdot$ Appeals $\cdot$ Administrative tribunals $\cdot$ Administrative law $\cdot$ Procedural fairness $\cdot$ Judicial review $\cdot$ Legal $\cdot$ Canada

Within this chapter, we discuss the overarching legal framework in Canada as it applies to student academic misconduct in post-secondary institutions. We also highlight some important cases in which academic misconduct decisions have been appealed to or judicially reviewed by the Courts. Our goal is to provide postsecondary institutions with the necessary information to create fair and sound policies, that would ultimately be supported by the post-secondary community and the Courts. This chapter does not examine in detail, although some examples are provided, the different approaches taken by post-secondary institutions across Canada, or make judgements on whether those approaches would be seen as fair and appropriate in law.

The number of cases in which findings of academic misconduct have been challenged in the Courts is small. However, these cases are illustrative of the balance

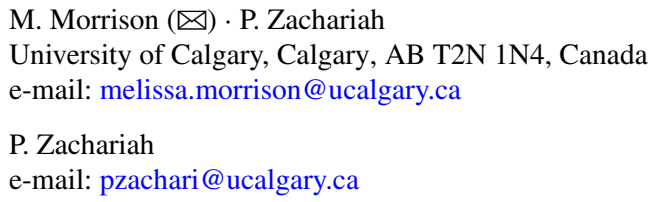

M. Morrison $(\bowtie) \cdot$ P. Zachariah

University of Calgary, Calgary, AB T2N 1N4, Canada

e-mail: melissa.morrison@ucalgary.ca

P. Zachariah

e-mail:pzachari@ucalgary.ca

S. E. Eaton and J. Christensen Hughes (eds.), Academic Integrity in Canada,

Ethics and Integrity in Educational Contexts 1 ,

https://doi.org/10.1007/978-3-030-83255-1_28 
between the expertise and autonomy of post-secondary institutions to safeguard the academic integrity of the academy versus the duty of fairness and reasonability owed to their students. Post-secondary institutions must find an appropriate balance between deterrence and compassion, justice and education. The highly legal approach that post-secondary institutions have traditionally taken in Canada to dealing with academic misconduct may have kept the number of cases that get challenged in the Courts low. However, does such a dearth of cases imply that post-secondary institutions are finding the right balance? We are mindful of the alternatives to the traditional, adversarial approach to handling academic misconduct and the value of embracing the recommendations in the Truth and Reconciliation Commission ${ }^{1}$ in order to facilitate the adoption of broader models of Justice.

\section{Academic Misconduct: The Canadian Legislative and Policy Context}

Canadian post-secondary institutions are for the most part creations of statute and the ability to oversee academics in general, including the power to discipline for issues like academic misconduct, flows from this legislation. As an example, Alberta's Post-Secondary Learning Act (Government of Alberta, 2020) speaks generically to the power of the General Faculties Council over "student affairs". It also specifically articulates the ability to discipline students, with such discipline including fines, suspension and expulsion. This power to discipline is subject only to the right of appeal to the institution's Board of Governors ${ }^{2}$.

This governing legislation establishes the broad structure required for postsecondary institutions to govern themselves, along with some specific requirements around how to conduct their affairs. With that in mind, all decisions that result in discipline of a student because of academic misconduct must be made within the legislative governance framework established by the relevant statute or the postsecondary institution runs the risk of having a court find their action(s) or decision(s) beyond their authority or jurisdiction.

Post-Secondary learning is regulated under Provincial jurisdiction, as per the Constitution Act, $1867 \mathrm{~s} .93^{3}$. The provinces exercise their jurisdiction over postsecondary learning institutions in a variety of ways.

For example, some provinces such as Ontario, have individual pieces of legislation which establish the governing structure of a specific post-secondary institution.

\footnotetext{
${ }^{1}$ Truth and Reconciliation Commission of Canada., United Nations., National Centre for Truth and Reconciliation., Truth and Reconciliation Commission of Canada \& United Nations (2015). Truth \& Reconciliation: Calls to Action.

${ }^{2}$ Post-Secondary Learning Act, Statutes of Alberta (2003, c.P-19.5) s.31. Retrieved from Alberta Government website: https://www.qp.alberta.ca/documents/acts/p19p5.pdf

${ }^{3}$ The Constitution Act, 1867 (UK), 30 \& 31 Victoria, c 3.
} 
Most other provinces have a single, overarching statute that provides for the governance of all post-secondary institutions ${ }^{4}$. However, what is mostly universal across the country (Kelleher, 2016) is the legislative establishment of a similar bicameral governance model with the creation of a Board of Governors and a Senate. ${ }^{5}$ A Board of Governors, which is usually appointed by government and specific stakeholder groups within the institution, is typically responsible for the ongoing operational direction of the institution. The academic Senate, comprised of representation from the post-secondary community, is broadly responsible for the academic affairs of the institution. Legislation also identifies the senior officers of the institution e.g., President, Provost, Deans, etc.

Flowing from the enabling legislation, a post-secondary institution can create the structures and procedures to deal with allegations of academic misconduct involving students. Whatever structure or procedure is created, there must be clear jurisdiction granted by the appropriate governing authority as established by the legislation. Taking Alberta's legislation as an example once again, it would be important that postsecondary institutions in that province ensure that general policy and process around academic misconduct occur through General Faculties Council oversight, with a robust process to deal with student appeals of discipline to the Board of Governors. Alberta's Post-Secondary Learning Act speaks to the ability of the General Faculties Council to delegate its power to discipline to other bodies or persons allowing greater flexibility in process and structure to address issues.

There will be numerous campus entities with different roles and responsibilities, which collectively promote and support the institution's academic integrity, including faculty, academic units, Registrar, Secretariat, student services (i.e., Student Ombuds or Advocate). It is important that there are clear and coherent policies and procedures that delineate the different roles and responsibilities among these various entities. Typically, such policies also provide direction on what a suitable range of penalties might be for various types of infractions, depending on whether it is a first or subsequent offence, the severity of offence, etc. This is meant to encourage consistency across departments. Given faculty reluctance to bring cases forward, having a straightforward process that faculty view as reasonable can be helpful in encouraging the formal resolution of such incidents (see Christensen Hughes \& McCabe, 2006).

\footnotetext{
${ }^{4}$ Examples include:

British Columbia: University Act, Revised Statues of British Columbia (1996, c.468). Retrieved from British Columbia Government website https://www.bclaws.gov.bc.ca/civix/document/id/com plete/statreg/96468_01

Alberta: Post-Secondary Learning Act, Statutes of Alberta (2003, c.P-19.5) s.31. Retrieved from Alberta Government website: https://www.qp.alberta.ca/documents/acts/p19p5.pdf

${ }^{5}$ Kelleher, William Edward (2016). Canadian Laws Relevant to University Student Academic Discipline (ProQuest Number 10253968) [Doctoral Dissertation, Northcentral University]. Retrieved from ProQuest website https://search-proquest-com.ezproxy.lib.ucalgary.ca/docview/1867763133? pq-origsite= primo
} 
When adjudicating academic misconduct, an institution's specific policies must also adhere to any provincial legislation that governs the functioning of administrative decision-making tribunals ${ }^{6}$. In provinces where such legislation is in force, a post-secondary institution needs to consider its application to their decision-making processes and ensure adherence to its requirements.

In addition to enabling legislation, provincial statute and institutional policy, the Canadian Charter of Rights and Freedoms (1982) may apply to certain decisions which exercise a post-secondary institution's authority to deal with academic misconduct allegations. Section 32 of the Charter states that it applies to actions of the Federal government, and "to the legislature and government of each province in respect of all matters within the authority of the legislature of each province". Therefore, the application of the Charter depends on the extent to which the prescribed action is determined by legislation or is the result of direct government action. The application of the Charter to the conduct of post-secondary institutions remains subject to contextual argument. However, in the case of Prigden v. The University of Calgary $(2012)^{7}$, the Alberta Court of Appeal found that the ability of the University to impose sanction pursuant to the Post-Secondary Learning Act was "beyond the authority held by private individuals or organizations" 8 . As such, the court rejected the University's position that the application of the Charter undermined academic freedom and found that "in exercising its statutory authority to discipline students for non-academic misconduct, it is incumbent on the Review Committee to interpret and apply the Student Misconduct Policy in light of the students' Charter rights, including their freedom of expression". ${ }^{9}$ Thus, the potential application of the Charter to decisions of post-secondary institutions with respect to student academic misconduct remains contextual, with focus on the statutory framework at play, but still remains an important consideration. Post-secondary institutions should thus be mindful of how their actions and processes impact a student's Charter rights, which include freedom of expression, freedom of association and security from unreasonable search and seizure.

\section{Addressing Academic Misconduct: Learning from the Courts}

While the goal is for educational institutions to approach teaching, learning, and assessment in ways that foster academic integrity and minimize the potential for misconduct, there are circumstances that require a heavier response. If a postsecondary institution is seen as having ignored or brushed aside alleged instances of

\footnotetext{
${ }^{6}$ Example: Statutory Powers Procedure Act, Revised Statutes of Ontario (1990 c.S.22) Retrieved from Ontario Government website https://www.ontario.ca/laws/statute/90s22

${ }^{7}$ Pridgen v. University of Calgary (2012) ABCA 139.

${ }^{8}$ Ibid. at para. 105.

${ }^{9} \mathrm{Ibid}$ at para. 112 and 113.
} 
serious or repeated academic misconduct, the integrity of the school will be undermined and students may become ambivalent toward completing their work with integrity.

As such, post-secondary institutions need to have a fair and robust process to investigate and address alleged instances of academic misconduct. This process needs to accord with legislative requirements, if they exist, as well as mesh with the institution's values, policies, procedures, and practices. These processes also need to follow legal principles established by the courts as decisions about academic misconduct could have a significant impact on a student's life. Decisions about whether a student has committed academic misconduct and any resulting discipline or sanctions are administrative decisions that are subject to judicial scrutiny, primarily ${ }^{10}$, though not exclusively, through the process of judicial review of the appropriateness of the decision, and whether the process followed in making the decision met the basic tenets of procedural fairness. "The fact that a decision is administrative and affects "the rights, privileges or interests of an individual" is sufficient to trigger the application of the duty of fairness."11

The degree of procedural fairness owed in a particular circumstance is a contextual analysis and involves the review of a number of factors ${ }^{12}$, including: the nature of the decision being made, the statutory regime, the importance of the decision to the individuals affected, the legitimate expectations of those individuals, and the procedures chosen by the decision-maker. ${ }^{13}$ While historically there has been a high degree of deference paid to decisions made by Universities, especially those decisions that directly relate to academics, decisions that have a larger impact on a person require a higher degree of procedural fairness. ${ }^{14}$

The Supreme Court of Canada, in the case of Khan v. The University of Ottawa, spoke to a requirement for a high level of procedural fairness for decisions that involve academic discipline. By extension, the more significant the discipline, the more procedural fairness will be required. In Khan, for example, the Supreme Court of Canada found that a "university student threatened with the loss of an academic year by a failing grade is also entitled to a high standard of justice". ${ }^{15}$ Generally, the concept of procedural fairness and the underlying values that support this concept "relate to the principle that the individual or individuals affected should have the opportunity to present their case fully and fairly, and have decisions affecting

\footnotetext{
${ }^{10}$ The focus of this Chapter is on judicial review of academic misconduct decisions. However, actions in tort and breach of contract may be available to a student as well.

${ }^{11}$ Cardinal v. Director of Kent Institution, [1985] 2 SCR 643, para. 653. Retrieved from Supreme Court of Canada website https://scc-csc.lexum.com/scc-csc/scc-csc/en/item/106/index.do

${ }^{12}$ Baker v. Canada, [1999] 2 SCR 817, para. 21. Retrieved from Supreme Court of Canada website https://scc-csc.lexum.com/scc-csc/scc-csc/en/item/1717/index.do

${ }^{13} \mathrm{Ibid}$. at para. $23-27$.

${ }^{14}$ Dunne v. Memorial University of Newfoundland, [2012]. NLTD(G) 41 at paras. 7 and 17.

${ }^{15}$ Khan v. University of Ottawa (1997) 34 OR 535 para. 9. Retrieved from CanLII https://www.can lii.org/en/on/onca/doc/1997/1997canlii941/1997canlii941.html
} 
their rights, interests, or privileges made using a fair, impartial, and open process, appropriate to the statutory, institutional, and social context of the decision"16.

In Dunsmuir v New Brunswick ${ }^{17}$, the Supreme Court of Canada said the following about procedural fairness:

Procedural fairness is a cornerstone of modern Canadian administrative law. Public decision makers are required to act fairly in coming to decisions that affect the rights, privileges or interests of an individual. Thus stated the principle is easy to grasp. It is not, however, always easy to apply.

The courts have further defined the basic hallmarks of procedural fairness and the degree to which decision makers have to ensure compliance with these requirements. While not all have considered them specifically in the context of academic misconduct, they have been reviewed in circumstances that similarly attract a higher degree of procedural fairness.

\section{The Right to an Unbiased Decision Maker}

It is important that decision makers view their role and the decision before them in a manner that is free from bias. The courts do not look at whether there is actual bias, but if there is a "reasonable apprehension of bias" in the circumstances. Particular caution must be paid to avoiding circumstances where decision makers have overlapping roles or jurisdiction over issues involving academics in general and academic misconduct decision making. ${ }^{18}$ This can be particularly problematic in post-secondary institutions where leadership may have broad and intersecting oversight over multiple aspects of academic and student life. It is also important to prevent scenarios where a party in the process acts as both a complainant (accuser) and the decision maker or where their role as either may be influenced or reasonably seen as influenced by the other or other parties within the institution. In cases where individuals participate in multiple layers of the investigation and appeal process for academic misconduct, institutions must ensure their roles are insulated from bias or conflict.

In Wilson v. The University of Calgary (2014) at paragraph 69, the court highlighted this concern of overlapping roles, but was clear that there are always exceptions like in cases where it is specifically allowed by statute.

By extension, it is important for post-secondary institutions to put measures in place to avoid issues of reprisal in relation to findings of academic misconduct. For

\footnotetext{
${ }^{16}$ Alberta (Funeral Services Regulatory Board) v. Strong [2006] ABQB 873 para. 25. Retrieved from CanLii https://www.canlii.org/en/ab/abqb/doc/2006/2006abqb873/2006abqb873.html?result Index $=1$

${ }^{17}$ Dunsmuir v. New Brunswick (2008) 1 SCR 190 at para. 70. Retrieved from CanLii https://www. canlii.org/en/ca/scc/doc/2008/2008scc9/2008scc9.html?resultIndex=1

${ }^{18}$ Wilson v. University of Calgary (2014) ABQB 190 para. 67. Retrieved from Canlii https://www. canlii.org/en/ab/abqb/doc/2014/2014abqb190/2014abqb190.html?resultIndex=1
} 
many students, committing academic misconduct is a singular transgression in their academic journey, which may be overcome through academic integrity education. Ensuring that the processes to address allegations of academic misconduct respect an accused student's privacy (i.e. confidentiality of process, minimize number of participants) is an important starting point. Students who have been found to have committed academic misconduct, or who have appealed a finding, may have legitimate concerns about whether they will be fairly evaluated by instructors in the future and post-secondary institutions need to be ready to respond to those issues.

\section{The Requirement to Provide Notice, the Disclosure of the Case to Be Met and the Right to be Heard}

While each of these terms appear to be easy to understand and common sense in their application, they are often the areas that decision makers have the most difficulty with in practice.

The requirement to provide notice, at its most basic level, means providing notice to affected parties that a decision is going to be made. Most obviously, this notice must be provided to the person who the decision is about. However, this may also extend to notice to other individuals who may be peripherally impacted by the decision. ${ }^{19}$

The notice provided must answer the who, what, where, why and how of the decision to be made or the issues that form the basis for the decision. It should outline the process that will be followed prior to a decision being made, as well as the potential outcomes.

The process leading up to a decision will require an opportunity for the student accused of academic misconduct to respond to the allegations. This is of critical importance. That may be in a formal hearing setting or more simply in a face to face discussion. Regardless, the accused student must be given enough time to prepare their response. The goal is not to ambush or to surprise them. The amount of time required for notice is once again dependent on the context and cases with a higher degree of complexity or with more serious potential outcomes or sanctions will require more notice. ${ }^{20}$

As part of the right to respond, someone accused of academic misconduct must be given the opportunity to review and respond to all evidence that the decision maker relied upon in making their decision. Again, this does not mean ambushing an accused student during the course of a hearing or in an interview, but giving this information to them in advance in order to be able to fully review and respond to this evidence. Decision makers often have a difficult time determining what evidence they

\footnotetext{
${ }^{19}$ Saskatchewan Ministry of Justice and Attorney General. Ombuds Saskatchewan: Practice Essentials for Administrative Tribunals. Regina, 2020. at pg. 17. Retrieved from Government of Saskatchewan website https://ombudsman.sk.ca/app/uploads/2020/03/Practice-Essentials-Finalwith-Cover.pdf

${ }^{20}$ Ibid.
} 
actually relied on and only provide evidence that supports the outcome or decision they made. However, they must disclose all relevant evidence even if it was discounted by the decision maker.

In cases where there are concerns around confidentiality or a desire for anonymity, the decision maker must weigh the competing interests in determining what should be disclosed. The default position should always be disclosure out of fairness to the individual accused of academic misconduct with holding back evidence happening in cases where there is very compelling reasons to do so, like the harm resulting from the disclosure outweighing any fairness achieved from its inclusion. "The fact that a person would prefer to have certain information kept confidential is not enough for non-disclosure." 21

\section{The Right to Counsel}

The right to legal counsel is not absolute. ${ }^{22}$ Again, a contextual analysis is required to determine whether the right to have the support of legal counsel is required to meet a post-secondary institution's procedural fairness obligations when it comes to academic misconduct decisions.

Generally, the more formality and complexity in the process and issues, the more likely it is that a student will require the support of legal counsel in order to fairly respond to the case against them. In Wilson ibid, the court did not find that the exclusion of legal counsel was a breach of the student's right to counsel and stated the following:

This is not an instance where the talents of a lawyer were required in order to ensure adequate presentation of the Applicants' position. The facts were not in dispute. There were no witnesses called by either side. The nature of the proceedings was meant to be informal. $^{23}$

With that in mind, cases where there are fundamental disputes on the facts that support the allegations of misconduct, the involvement of witnesses to speak to those facts, the formality of the process and the degree to which credibility must be assessed all weigh into the analysis around whether a student should be allowed to be supported, and the degree of the support provided, by legal counsel.

Across the country, post-secondary institutions have a variety of approaches when it comes to allowing counsel to assist a student. These include:

- No right to counsel whatsoever;

- The right to counsel or an advisor, but with some clear exceptions (advisor cannot be a family member);

\footnotetext{
${ }^{21}$ Ibid.

${ }^{22}$ Pridgen v. University of Calgary (2012) ABCA 139 para. 78. Retrieved at CanLII https://www. canlii.org/en/ab/abca/doc/2012/2012abca139/2012abca139.html?resultIndex=1

${ }^{23}$ Ibid. para. 82.
} 
- Access to a student advocate;

- The right to an advisor, who may be legal counsel or anyone else, but who cannot take an active role in the process;

- The universal right to counsel, whether it be legal counsel or someone else of the student's choosing.

Given the contextual analysis required to determine whether a student should have the right to counsel or not, some of these may meet the threshold for procedural fairness in some cases, but not in others. Allowing for a more fluid position on the involvement of counsel which responds to the level of complexity of the case is best. This may be a formal request for counsel which can be decided on a case by case basis.

\section{The Right to an Oral Hearing and to Cross Examine Witnesses}

Much like many procedural fairness elements, the right to an oral hearing and to cross examine witnesses is not a standard requirement in all cases. The nature of the allegations of misconduct and the potential outcome help define whether a full oral hearing, with the ability to cross examine witnesses, is required or if a written hearing is sufficient. Additionally, it is important to determine whether governing legislation dictates the requirement to conduct an oral hearing.

As is generally the case with administrative decisions, the more serious the potential outcome, the higher degree of procedural fairness will be owed to a student. However, it is critically important to review the allegations against the student, as well the relevant evidence, when determining whether an oral hearing is required. Cases that have critical factual disputes, issues where credibility will need to be assessed, or matters that require oral submissions for a student to be able to sufficiently respond to the allegations, should have an oral hearing with an opportunity to cross examine witnesses. ${ }^{24}$

One challenging aspect is how to manage a student's access to witnesses or how to compel witnesses to participate in an academic misconduct process. Generally, a post-secondary institution will not have the ability to compel or force a witness to take part in an academic misconduct investigation or hearing. However, it is critically important that the post-secondary institution is seen to have done enough to facilitate access to witnesses or conversely not be seen to have obstructed that access. If key witnesses have not provided evidence or not been willing to be cross examined, the post-secondary institution will need to thoughtfully consider how to factor that in to the decision.

\footnotetext{
${ }^{24}$ Wilson v. University of Calgary (2014) ABQB 190 para. 84. Retrieved from Canlii https://www. canlii.org/en/ab/abqb/doc/2014/2014abqb190/2014abqb190.html?resultIndex=1
} 


\section{The Person Who Hears the Case Must Decide It}

Decision making in educational institutions is often structured in a way that allows for someone in a senior leadership role to make the final decision on a matter (i.e., President, Provost, Dean), and it is sometimes the case that these individuals were not a part of the detailed review that took place. Commonly, this occurs through recommendations from the investigator(s) to the decision maker. While this is not necessarily wrong, it can be problematic in light of the very important concept in the duty of fairness that the person who hears the case should be the one who decides the case.

The purpose of this concept is to limit the influence of third parties on the decision making process. ${ }^{25}$ It is best practice to have the party who has examined the evidence and made any credibility assessments to be the one responsible for the decision. In cases where a institution absolutely requires a senior official to make the final decision, ideally they would be directly involved in hearing and reviewing all of the relevant evidence. Where this is not possible, it should only be in the rarest of circumstances that the decision is contrary to those recommendations. In those cases, a court will want to see compelling reasons why the decision maker chose to deviate from the recommendations of the investigator(s).

\section{The Right to Reasons}

When a decision has a significant impact on a student's academic career and personal circumstances, they should be provided with the detailed written reasons in support of the decision. In considering what degree of procedural fairness should be afforded an individual who had applied for permanent residence for compassionate reasons, the Supreme Court of Canada found that "it would be unfair for a person subject to a decision such as this one which is so critical to their future not to be told why the result was reached".

Reasons foster better decision making and accord with principles of transparency and fairness. ${ }^{26}$ Reasons should not be template, but responsive to the unique case before the decision maker. The reasons should support the decision arrived at while adequately explaining why evidence contrary to the decision was not accepted. Reasons are particularly important when there have been factual disputes or issues where credibility has been assessed in order to provide the decision maker's reconciliation of those pieces that are at odds.

\footnotetext{
${ }^{25}$ Saskatchewan Ministry of Justice and Attorney General. Ombuds Saskatchewan: Practice Essentials for Administrative Tribunals. Regina, 2020. Retrieved from Government of Saskatchewan website https://ombudsman.sk.ca/app/uploads/2020/03/Practice-Essentials-Final-with-Cover.pdf ${ }^{26}$ Baker v. Canada, [1999] 2 SCR 817, para. 38. Retrieved from Supreme Court of Canada website https://scc-csc.lexum.com/scc-csc/scc-csc/en/item/1717/index.do
} 


\section{Creating a Fair Process to Address Academic Misconduct}

The jurisprudence on administrative decision making, and the specific cases dealing with decisions arising from the post-secondary environment, lay the foundation for creating a process that handles academic misconduct allegations and adheres to best practices.

In determining the best way to address academic misconduct allegations, the first step is to determine the style of process to follow. The following are the different models that a post-secondary institution can adopt to handle academic misconduct allegations: ${ }^{27}$

(1) Traditional Adversarial Hearing: this model is based on how the courts handle cases. It will feel more formal and adhere to stricter principles of conduct. The parties, who are in opposition with one another, present their cases to the decision maker. The decision maker relies on the parties to bring forward the evidence and argue the issues.

The Traditional Adversarial Hearing model is commonly used at the appeal stage. The appeal can be heard and determined either by an individual or a committee composed of a cross section of the post-secondary community and will convene when an appeal is brought against a finding of academic misconduct, or the penalty that is imposed. Some post-secondary institutions allow only a student to appeal findings of academic misconduct, while other institutions explicitly also allow administration to appeal findings as well. Most commonly it is left undefined as to which party may appeal a decision.

In this model, the right to appeal a decision is typically not absolute. Usually, the party wishing to bring an appeal of a decision must first demonstrate that they have proper grounds to support that there was a flaw in the decision. Common grounds include (a) that the decision was unreasonable based on the evidence before the original decision maker, (b) the original decision was made without procedural fairness, (c) the original decision maker showed bias or (d) that there is new evidence which was not available to the original decision maker, that has direct bearing on the reason for a finding of academic misconduct by the original decision maker.

While the format of a traditional adversarial hearing will differ across postsecondary institutions, a common feature is each side presenting their evidence in the presence of the other party. There is generally symmetry to a hearing, with each side taking turns presenting their evidence and fielding questions. Once one party has presented their case, the other party must have an identical opportunity to present and take questions. While it is common for the hearing panel to ask questions of the parties, the ability for a party to cross-examine the other is variable, with some institutions specifically not allowing cross examination.

\footnotetext{
${ }^{27}$ Saskatchewan Ministry of Justice and Attorney General. Ombuds Saskatchewan: Practice Essentials for Administrative Tribunals. Regina, 2020 at pg. 39. Retrieved from Government of Saskatchewan website https://ombudsman.sk.ca/app/uploads/2020/03/Practice-Essentials-Finalwith-Cover.pdf
} 
A fairly representative example of the Traditional Adversarial Hearing model is the University of Guelph. In that system, appeals are heard by the Senate Committee on Student Petitions ${ }^{28}$, whose jurisdiction and powers are governed via Terms of Reference.

The challenges with this approach is the decision maker is entirely dependent on the parties to bring the issues and evidence to the hearing. This is especially deleterious where a party has an otherwise compelling case but is disorganized or incomplete in their presentation. The inability of either side to present relevant evidence, or to compel credible witnesses, can also hinder the efficacy of the Traditional Adversarial Model. The formality of this approach may also create significant stress on the parties.

(2) An Investigation Model: this model requires the decision maker to gather all of the evidence and question all parties who may have information about the allegations. The investigation is concluded with a decision being made.

In this model, the allegation of academic misconduct is usually made by an instructor or teaching assistant, who will report their suspicions and any supporting evidence to a designated investigator and/or decision maker. The decision maker will then review the relevant documents and interview the student or any other relevant witnesses to determine whether academic misconduct has occurred. Decisions are supported by the evidence gathered during the course of the investigation.

The decision maker has the authority and discretion to apply penalties. However, the decision maker is often constrained by directives which limit the range of penalties that can be applied in particular types of academic misconduct. For example, first time offenders may receive a warning or educational support, while subsequent findings of academic misconduct may invite greater penalties such as a failure of a course or suspension from the post-secondary institution.

The University of Calgary follows an Investigation Model when allegations of academic misconduct are raised. In the University of Calgary system, instructors must submit a written report of all incidents of suspected academic misconduct to faculty leadership. Students, or other individuals with evidence of academic misconduct, can also report allegations. Once leadership receives an allegation, there is a recommended time frame in which the student must be informed of the allegation and whether an investigation will be initiated. If an investigation is to be initiated, then the student must be informed of the nature of the allegation and all the evidence that has been collected. In addition, students are invited to meet to discuss the allegation in the presence of an advisor. There is a time limit for providing a written decision and if there is a finding of academic misconduct, the support for that finding and the consequences for the student.

The challenge with an investigation model is it does not typically offer an opportunity to either party to cross examine witnesses or challenge statements that may

\footnotetext{
${ }^{28}$ University of Guelph. (October 9th 2013) Senate Committee on Student Petitions, Committee ByLaws. Retrieved from https://www.uoguelph.ca/secretariat/office-services/senate/senate-boardsand-standing-committees/senate-committee-student-petitions
} 
have been brought forward about the allegations. This model tends to work better in cases where the evidence is entirely documentary in nature (i.e., no witnesses) or where there in an internal right of appeal.

An Inquiry Model: similar to the investigation model, this approach entails the decision maker seeking out all of the evidence, but in the course of a hearing. The decision maker is the one responsible for asking the questions and gathering the evidence. This model has benefits which include putting the control of the process in the hands of the decision maker. However, with this control comes a significant amount of responsibility, which may make the process quite lengthy especially if a post-secondary institution has multiple cases of alleged academic misconduct.

This model is not typically seen in Canada's post-secondary environment with respect to academic misconduct.

(3) A Hybrid Model: There has been an increasing shift towards systems that incorporate features of both the Investigative model and Traditional Hearing model. Such systems are aimed at providing a more holistic approach to dealing with allegations of academic misconduct.

An example of a hybrid model is currently used by the Ryerson University. In the Ryerson system, allegations of academic misconduct are made to Designated Decision Makers, who are a pool of faculty who have been trained in investigations. Their process is unique as Designated Decision Makers have more flexibility in how they address findings of academic misconduct, which may include meeting with students through a "facilitated or non-facilitated discussion" to discuss possible outcomes such as attending an educational workshop or participating in an online quizzes to ensure the expectations of the institution are understood. ${ }^{29}$

\section{Academic Misconduct Decisions: Judicial Review}

Courts have a form of oversight. Because of the significant impact of these decisions on students, the Courts have typically found greater need for judicial intervention.

Judicial review will typically look at two aspects of the decision: 1. Was the decision made in a procedurally fair way?; and 2 . Is the decision fair and reasonable? If the Court determines that the post-secondary institution did not meet its procedural fairness requirements, the decision will be overturned and one of a number of possible remedies will be ordered.

When assessing whether a post-secondary institution made a fair and reasonably justifiable decision, however, the Courts will first have to determine which standard of review they will apply to that decision. There are two potential standards of review that a Court will apply to the decision: correctness and reasonableness. The choice of the standard of review reflects how much judicial deference the Court should show

\footnotetext{
${ }^{29}$ Ryerson University (2019), Ryerson University Policy of Senate, Academic Integrity. Retrieved from Ryerson website https://www.ryerson.ca/content/dam/senate/policies/pol60.pdf
} 
the decision maker. If the Court decides to show deference, then reasonableness is the standard. If the Court decides that no judicial deference is warranted, the standard will be correctness.

If the standard of review is correctness, "a reviewing court will not show deference to the decision maker's reasoning process; it will rather undertake its own analysis of the question." 30 Therefore, if the standard of correctness is applied to a decision of academic misconduct, the court can proceed to directly consider how it would have decided the matter if it was in the place of the decision maker.

The reasonableness standard recognizes that "certain questions that come before administrative tribunals do not lend themselves to one specific particular result and may "give rise to a number of possible, reasonable conclusions." Instead of proceeding directly to consider how it would have decided the matter, a reviewing court "is concerned mostly with the existence of justification, transparency and intelligibility within the decision-making process". 31

Until recently, the leading case used to determine the applicable standard of review was Dunsmuir v. New Brunswick. In Dunsmuir, the Supreme Court of Canada established indicators to help determine the proper standard of review. This analysis could be described as challenging to navigate. The Supreme Court of Canada has tried to simplify and clarify how to determine the proper standard of review in the case of Canada (Minister of Citizenship and Immigration) v. Vavilov, 2019 SCC 65. In this case, the Supreme Court has held that there is a general presumption that the standard of review is reasonableness to any substantive decision made by a statutory decision maker. However, the presumption of reasonableness is rebutted if (1) the governing legislation indicates that a standard other than reasonableness that should apply, and (2) rule of law principles require that a different standard of review should apply to the decision. In the first instance, the analysis is prescriptive. In the second instance, the analysis is contextual.

While it is currently still too early to fully appreciate the effect that Vavilov will have on the practice of academic misconduct at post-secondary institutions, some general principles can be identified. The general presumption of reasonableness as a standard of review will in most cases apply to post-secondary institutions' decisions about academic misconduct. However, what constitutes reasonable remains contextual.

The specialized expertise of a decision maker is a relevant factor in determining whether a decision was reasonable. Arguably, a decision maker in an academic misconduct process has more specialized expertise in academic integrity than someone outside of a post-secondary institution. The application of this specialized knowledge may reveal why particular attention or preference was given to some evidence or issues over others (Vavilov, para. 93).

\footnotetext{
${ }^{30}$ Dunsmuir v. New Brunswick [2008] 1 SCR 190 at para. 50. Retrieved from CanLii https://www. canlii.org/en/ca/scc/doc/2008/2008scc9/2008scc9.html?resultIndex=1

${ }^{31}$ Dunsmuir v. New Brunswick [2008] 1 SCR 190 at para. 48. Retrieved from CanLii https://www. canlii.org/en/ca/scc/doc/2008/2008scc9/2008scc9.html?resultIndex=1
} 
While the institutional context for the decision may attract judicial deference, the court cannot overlook non-transparency or gaps in logic in the process of the decision $^{32}$. The decision maker must demonstrate in the reasons how the evidence before them was considered and how the outcome is supported by the evidence that was presented. ${ }^{33}$ However, the reasons do not have to address each argument made by the parties. ${ }^{34}$ The reasons must demonstrate a connection, or a path of analysis between the evidence and the decision. Reasons that merely set out the submissions made by the parties and then immediately arrive at conclusions will rarely be sufficient to demonstrate a path of analysis. Therefore, extreme care must be taken in how decisions are written. Decision makers are encouraged to consult with their institution's legal support to ensure that the written decision is sufficiently transparent, justified and intelligible. Failure to do so will make any decision, no matter how obvious on its face, appear unreasonable.

On judicial review, courts will rarely substitute their own decision for that of the original decision maker. Rather, courts can offer a variety of remedies to the applicant. Such remedies are meant to cure the underlying defect in natural justice or procedural fairness, such that the decision regarding the allegation of academic misconduct can be seen as 'fair'.

The general remedies available under judicial review are certiorari (an order voiding the decision under review), prohibition (barring an administrative act on jurisdictional grounds), mandamus (compelling an administrative act), and quo warranto (challenging the right of a decision maker to exercise its ability to make a decision).

Using the remedies available at judicial review, a student may be able to overturn a decision of the post-secondary institution that affects their standing or attendance at the institution. A student who has been found to have committed academic misconduct on clear evidence may nevertheless have that decision voided by a court if there were procedural defects in how the otherwise sound decision was reached. For example, a student who has been suspended from an institution may be re-admitted if the decision suspending the student was not made strictly in accordance with the enabling legislation.

The costs of judicial review can be high in terms of institutional resources, and time. In addition to the legal costs of defending an application in court, instructors and administrators will have to devote time in preparing the defense. Often, this outlay in resources will have to be made long after the actual events that form the basis of the academic misconduct allegation happened. If an applicant is successful at judicial review, the matter may be sent back to the post-secondary institution for re-adjudication.

\footnotetext{
${ }^{32}$ Canada (Minister of Citizenship and Immigration) v. Vavilov [2019] SCC 65 at para. 95. Retrieved from CanLii https://www.canlii.org/en/ca/scc/doc/2019/2019scc65/2019scc65.html

${ }^{33} \mathrm{Ibid}$. at paras. 125 and 126.

${ }^{34} \mathrm{Ibid}$. at paras. 127 and 128.
} 


\section{Practical Considerations}

It is critically important to acknowledge that most students and academic leaders will not have a legal background and as a result, creating or participating in processes used to address academic integrity may be intimidating and overwhelming. Failure to support all stakeholders in the process could result in avoidance in addressing allegations of academic misconduct, as well as put students at a disadvantage when defending such allegations.

Students navigating academic misconduct policies, processes and investigations should be given access to knowledgeable support. This support does not necessarily need to have a legal background, but should be well versed in the post-secondary institution's policies, procedures, processes and be connected with key stakeholders. This may be a student advocate or student ombudsperson, or a law students advocacy organization on campus. This is commonly available in one form or another in postsecondary institutions across Canada. Additionally, access to explanatory literature about how the process typically unfolds and the respective rights of the parties can also be very beneficial.

Equally important is for academic leadership to have access to legal counsel as support in creating a fair and robust process for investigating and addressing academic misconduct, as well as to provide guidance in how to properly investigate and assess allegations as they come forward. Given the growing complexity of academic misconduct cases, legal counsel has an important role in ensuring fairness and in training academic leadership and faculty on investigation and decision making principles.

Fear of legal processes or the erroneous belief of the need for an "airtight case" can act to deter faculty from bringing forward allegations of academic misconduct. Additionally, historic processes that were overly arduous or slanted in the favour of students can also limit the number of cases which come to light. It is important to understand that academic misconduct need not be proven beyond a reasonable doubt. This is the standard of proof required for conviction in criminal cases. Academic misconduct must only be proven on the balance of probabilities standard of proof, meaning it is more likely than not to have occurred based on the evidence-a lower standard of proof than what is required for criminal charges.

The content in this Chapter highlights the complexity of the law when it comes to academic misconduct decisions and the importance of ensuring that all participants in the process are given access to the necessary support and guidance. It also underscores the need to examine alternate approaches to deal with academic misconduct, apart from just the traditional, highly legal approach taken by most post-secondary institutions. There remains mistrust by academic staff that traditional processes to address academic misconduct, which are often oppositional and adversarial, will lead to an unsatisfactory outcome. Final recourse to the courts is fraught with issues that stem from complex access to justice concerns (i.e., long times to get hearing dates, access to legal counsel etc.). This all speaks to the need to consider alternative dispute resolution, and varying perspectives on the concept of justice, and their place within the current post-secondary framework that responds to academic misconduct. 
Finally, it is time to examine whether penalty-based sanctioning represents the best outcome or if there are different ways to deter conduct, while setting students up for academic success and integrity going forward.

\section{References}

Christensen Hughes, J. M., \& McCabe, D. L. (2006). Academic misconduct within higher education in Canada. The Canadian Journal of Higher Education, 36(2), 1-21. http://journals.sfu.ca/cjhe/ index.php/cjhe/article/view/183537/183482

Dunne v. Memorial University of Newfoundland. (2012). NLTD(G) 41.

Dunsmuir v. New Brunswick. (2008). 1 SCR 190 https://www.canlii.org/en/ca/scc/doc/2008/200 $8 \operatorname{scc} 9 / 2008$ scc 9. html?resultIndex $=1$

Government of Alberta. (2020). Post-Secondary Learning Act. https://www.qp.alberta.ca/docume nts/acts/p19p5.pdf

Government of British Columbia. (2020). University Act, RSBC 1996 C.468 https://www.bclaws. gov.bc.ca/civix/document/id/complete/statreg/96468_01

Government of Ontario. (1990). Statutory Powers Procedure Act, Revised Statutes of Ontario (1990 c.S.22) https://www.ontario.ca/laws/statute/90s22

Kelleher, W. E. (2016). Canadian Laws Relevant to University Student Academic Discipline (ProQuest Number 10253968) [Doctoral Dissertation, Northcentral University]. https://searchproquest-com.ezproxy.lib.ucalgary.ca/docview/1867763133?pq-origsite=primo

Khan v. University of Ottawa. (1997). 34 OR 535 https://www.canlii.org/en/on/onca/doc/1997/199 7canlii941/1997canlii941.html

Pridgen v. University of Calgary. (2012). ABCA 139.

Ryerson University. (2019). Ryerson University Policy of Senate, Academic Integrity. https://www. ryerson.ca/content/dam/senate/policies/pol60.pdf

Saskatchewan Ministry of Justice and Attorney General. Ombuds Saskatchewan: Practice Essentials for Administrative Tribunals. (2020). https://ombudsman.sk.ca/app/uploads/2020/03/PracticeEssentials-Final-with-Cover.pdf.

University of Guelph. (2013). Senate Committee on Student Petitions, Committee By-Laws. https://www.uoguelph.ca/secretariat/office-services/senate/senate-boards-and-standing-commit tees/senate-committee-student-petitions

Wilson v. University of Calgary. (2014). ABQB 190 para. 67. https://www.canlii.org/en/ab/abqb/ doc/2014/2014abqb190/2014abqb190.html?resultIndex=1

Melissa Morrison B.com, LLB is a mother, wife and practicing lawyer in the Province of Alberta. She currently works as the Student Appeals Officer for the University of Calgary and, as part of her role, she provides advice to internal hearing tribunals on appeals of a variety of decisions, including academic misconduct findings, and also offers guidance on appropriate investigation techniques. With over 17 years in practice, Melissa has gained significant experience in litigation, health and administrative law, as well as student appeals and professional regulatory processes.

Philip Zachariah MA, JD has over 15 years of experience in legal practice with post-secondary institutions. He is currently Legal Counsel for the University of Calgary where he provides advice on a wide variety of issues from student appeals to commercial procurement to privacy and data security. Before that, he was the Judicial Officer at the University of Guelph, where he did an MA on the applicability of alternative dispute resolution models to addressing breaches of academic integrity. 
Open Access This chapter is licensed under the terms of the Creative Commons Attribution 4.0 International License (http://creativecommons.org/licenses/by/4.0/), which permits use, sharing, adaptation, distribution and reproduction in any medium or format, as long as you give appropriate credit to the original author(s) and the source, provide a link to the Creative Commons license and indicate if changes were made.

The images or other third party material in this chapter are included in the chapter's Creative Commons license, unless indicated otherwise in a credit line to the material. If material is not included in the chapter's Creative Commons license and your intended use is not permitted by statutory regulation or exceeds the permitted use, you will need to obtain permission directly from the copyright holder.

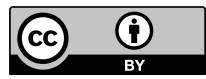

